NBER WORKING PAPER SERIES

\title{
RATIONAL AND BEHAVIORAL PERSPECTIVES ON THE ROLE OF ANNUITIES IN RETIREMENT PLANNING
}

\author{
Jeffrey R. Brown \\ Working Paper 13537 \\ http://www.nber.org/papers/w13537
NATIONAL BUREAU OF ECONOMIC RESEARCH
1050 Massachusetts Avenue
Cambridge, MA 02138
October 2007

This paper was written for the book edited by Anna Maria Lusardi, entitled Overcoming the Saving Slump: How to Increase the Effectiveness of Financial Education and Saving Programs. The author is grateful to John Ameriks, Andrew Caplin, Anna Maria Lusardi, and participants in the May, 2007 "Improving the Effectiveness of Financial Education and Savings Programs" conference for helpful conversations. The views expressed herein are those of the author(s) and do not necessarily reflect the views of the National Bureau of Economic Research.

(C) 2007 by Jeffrey R. Brown. All rights reserved. Short sections of text, not to exceed two paragraphs, may be quoted without explicit permission provided that full credit, including $(\subset$ notice, is given to the source. 
Rational and Behavioral Perspectives on the Role of Annuities in Retirement Planning Jeffrey R. Brown

NBER Working Paper No. 13537

October 2007

JEL No. G11,H55,J14

\begin{abstract}
$\underline{\text { ABSTRACT }}$
This paper discusses the role of annuities in retirement planning. It begins by explaining the basic theory underlying the individual welfare gains available from annuitizing resources in retirement. It then contrasts these findings with the empirical findings that so few consumers behave in a manner that is consistent with them placing a high value on annuities. After reviewing the strengths and weaknesses of the large literature that seeks to reconcile these findings through richer extensions of the basic model, this paper turns to a somewhat more speculative discussion of potential behavioral stories that may be limiting demand. Overall, the paper argues that while further extensions to the rational consumer model of annuity demand are useful for helping to clarify under what conditions annuitization is welfare-enhancing, at least part of the answer to why consumers are so reluctant to annuitize will likely be found through a more rigorous study of the various psychological biases that individuals bring to the annuity decision.
\end{abstract}

Jeffrey R. Brown

Department of Finance

University of Illinois at Urbana-Champaign

340 Wohlers Hall, MC-706

1206 South Sixth Street

Champaign, IL 61820-9080

and NBER

brownjr@uiuc.edu 
"... It is a well known fact that annuity contracts, other than in the form of group insurance through pension systems, are extremely rare. Why this should be so is a subject of considerable current interest. It is still ill-understood." Franco Modigliani, Nobel Prize acceptance speech, December 9, 1985, Stockholm, Sweden. ${ }^{1}$

\section{Introduction}

Individuals engaged in financial planning for retirement have no shortage of resources available to provide guidance on how much to save and how to invest those savings. If one does a Google search on the term "retirement planning," the lion's share of the over 1.2 million hits appear to guide one to websites that discuss various features of the saving and investment decisions. Given the dominant focus on saving and investment, the typical worker could be forgiven for believing that "retirement planning” is synonymous with "wealth accumulation."

While wealth accumulation is an important ingredient in any financial plan, it is not sufficient to ensure financial well-being in retirement. A particularly glaring shortcoming of the focus on wealth accumulation is that it fails to consider how one's assets will be converted into a stream of consumption in retirement. A comprehensive retirement planning strategy requires that one think more than about how to save: it also requires thinking about how to spend.

Converting wealth into consumption is made difficult by the various risks facing individuals, such as uncertainty about how long one will live. Life annuities are financial contracts designed to insure against the financial risk created by length-of-life uncertainty by allowing an individual to exchange a lump-sum of wealth for an income stream that is guaranteed to last for the rest of the annuitant's life. While life annuities play an important role in the economics literature, the insurance features of life annuities appear to be poorly understood and/or "under-valued" by the general public, as evidenced by the very small size of the market. Many financial planning calculators simply ignore uncertainty about length-of-life,

\footnotetext{
${ }^{1}$ Modigliani (1986).
} 
or handle it in a naïve way, such as by creating a financial plan with a horizon equal to one's average remaining life expectancy plus five or ten years. Because these approaches ignore uncertainty, the retirement planning process becomes framed in a manner that does not provide a clear role for insurance against low consumption at advanced ages. Anecdotal evidences suggests that the lack of clarity on the benefits of annuities in reducing longevity risk also applies to financial planners and others who are engaged in the business of advising clients on how to prepare for retirement.

This paper examines the role of annuities in the financial planning process, including both the normative judgment about what role annuities “should” play (as guided by economic theory), as well as empirical evidence about the role that annuities actually do play. A key point is that there is a large gap between these two perspectives: much of the economics literature suggests that most individuals would find annuities welfare enhancing, and yet the empirical evidence suggests that individuals do not act as if they value them very highly. The economic literature that seeks to solve this annuity puzzle within a strictly rational framework has uncovered some important insights. To more fully understand why consumers behave as if they do not value annuities, however, it appears that the literature may need to move beyond the fully rational paradigm. The paper discusses several working hypotheses about behavioral biases that may influence annuity demand, while recognizing that these hypotheses have not yet been adequately tested in the literature. The paper concludes with a discussion of new developments in the annuity market that may overcome some of these demand limitations in the future. 


\section{Uncertain Lifetimes and the Role of Annuities}

In a world of certainty, financial planning for retirement would be easy: an individual could simply spread their wealth over a fixed time horizon. For example, an individual who prefers equal consumption in every period could simply amortize his wealth to provide constant real income each month until precisely running out of wealth on the last day of life.

In reality, of course, an individual faces several significant sources of uncertainty, including uncertainty about how long he will live, future expenditure needs (such as for uninsured medical expenses), and future real rates of return, among others. The financial implication of length-of-life uncertainty is that an individual must balance the risk of consuming too aggressively, which runs the risk of resulting in a large consumption drop at advanced ages, against the risk of consuming too conservatively, which will subject him to a lower of level of consumption than he could otherwise afford.

Life annuities are designed to eliminate longevity risk by allowing an individual to exchange a lump-sum of wealth for a stream of payments that continue so long as the individual (and possibly a spouse) is alive. Economic theory suggests that life annuities can substantially increase individual welfare by eliminating the financial risks associated with uncertain lifetimes and providing consumers with a higher level of lifetime consumption. One early and influential study showed that in the absence of bequest motives, risk averse individuals would find it optimal to annuitize 100 percent of their wealth. ${ }^{2}$

To understand this result, consider an individual without a bequest motive who cares only about his consumption in the current period and one period hence. If this individual invests $\$ 1,000$ in a non-annuitized asset with a rate of return 8 percent, then next period he will be able

\footnotetext{
${ }^{2}$ Yaari (1965) is the classic reference in this area. Later papers, including Bernheim (1987) and Davidoff, Brown and Diamond (2005) have shown that the central result holds even after relaxing many of the original assumptions.
} 
to consume $\$ 1,080$. On the other hand, if the individual invests $\$ 1$ in an annuity, and if with probability 0.03 the individual will not survive to receive the payment next period, then the insurer is able to pay $\$ 1,080 /(1-0.03)=\$ 1,102$ to the annuitant, conditional on survival. The extra return provided to surviving annuitants is sometimes called the "mortality premium” or “mortality credit,” because it is provided in return for giving up one's right to the wealth upon death. ${ }^{3}$ For an individual who does not value bequests, the fact that the rate of return on the annuity is greater than the rate of return on the non-annuitized asset for individuals who survive.

This potential for higher returns can be seen in figure 1, which shows the amount of income that would be available to an individual under several alternative strategies for converting one’s nest egg into retirement income. The “annuity” line shows the $\$ 7,704$ of annual income that would be available for life to a 65-year-old man who purchased a standard life annuity contract with an initial premium of $\$ 100,000 .{ }^{4}$ This strategy is then compared to three alternatives. The "self-annuitization” alternative shows an individual who invests his $\$ 100,000$ in a non-annuitized account earning the market rate of interest but who consumes the same $\$ 7,704$ per year in income that the life annuity would have provided. Because this individual is not benefiting from the mortality premium, this strategy is unsustainable: he would run out of money at age 85.

The "amortization" line shows another in which the individual invests his wealth at the going market interest rate and “amortizes” it (i.e., spreads it evenly) over 35 years, from age 65 to $100 .^{5}$ This strategy provides income that is nearly 25 percent lower than that provided by the annuity. Furthermore, the amortization strategy still imposes some risk; in the event that the

\footnotetext{
${ }^{3}$ For a discussion of mortality credits, see Milevsky (1998).

${ }^{4}$ Figure 1 and the accompanying text originally appeared in Brown (2004). Detailed assumptions underlying these calculations can also be found there.

${ }^{5}$ This calculation uses a 35-year nominal amortization at an interest rate of 4.58 percent.
} 
individual lives beyond age 100, he would have no money left to consume under this approach, whereas he would still have income if he had purchased a life annuity.

The "1 / LE," or “one divided by life expectancy,” line shows what happens if an individual follows a more "sophisticated" draw-down strategy that is similar to one of the methods permitted by the IRS for meeting minimum distribution requirements from qualified pension plans. In particular, the strategy is based on consuming a fraction of remaining wealth that is proportional to the individual's remaining life expectancy. ${ }^{6}$ The important feature of this approach is that, once again, the income stream is always lower than that provided by a life annuity. Indeed, the income from this approach never exceeds 94 percent of the annuity income level, and falls to less than 40 percent by the time a person is in his or her early 90 s.

These stylized results extend to more complex models, at least so long as the market for annuities is sufficiently well developed that individuals can match the annuity payouts to their desired consumption levels across time and across various resolutions of uncertainty. ${ }^{7}$ We know, of course, that the annuity market is not well-developed: for example, most annuities offered in the private sector lack inflation protection. ${ }^{8}$ Nor is there a rich market for products that combine annuities with other forms of insurance, such as the combined annuity and long-term care product that has recently been suggested. ${ }^{9}$ Still, simulations show that even when there is an extreme mismatch between the annuities provided by the market and the desired consumption path, a risk averse consumer would still find it optimal to annuitize the majority of his wealth. ${ }^{10}$ These simulations also show that while a bequest motive reduces the demand for annuities, it

\footnotetext{
${ }^{6}$ Life expectancy figures are drawn from the 2004 Social Security Trustee’s Report for the 1939 birth cohort - those turning 65 in the year 2004.

${ }^{7}$ Davidoff, Brown and Diamond (2005).

${ }^{8}$ An exception is the inflation indexed life annuity offered by AIG/Vanguard, although even this produce caps the inflation protection at 10 percent per year. A second exception is TIAA-CREF's Inflation Linked Bond Account, although this option is not available to retail investors.

${ }^{9}$ See, for example, Murtaugh, Spillman and Warshawsky (2001).

${ }^{10}$ Davidoff, Brown and Diamond (2005).
} 
does not eliminate it in general. In short, the economic literature provides a strong theoretical foundation for the normative conclusion that annuities ought to be of substantial value to retirees. It also has the positive empirical implication that we should observe annuities comprising a large component of individual and household portfolios.

\section{Do Consumers Behave as if they Value Annuities?}

The empirical evidence on annuitization suggests that individuals do not behave as if they value annuities as highly as theory would predict. This is evidenced by the fact that the private market for immediate annuities, or payout annuities, was only $\$ 11.8$ billion in $2005 .^{11}$ Even this may overstate the size of the payout annuity market, as included in the immediate annuity figures are some period certain products that pay out for a specified number of years with no life contingency. ${ }^{12}$ The conclusion that the market is small is supported by standard household data sets that are used to track asset ownership, such as the Survey of Consumer Finances or the Health and Retirement Study. The frequency with which annuity owners appears in these data sets is so low that empirical work on private market annuity purchases in the U.S. has been severely limited.

While annuitization is limited in the individual market, there has traditionally been a high level of annuitization provided through the group market via employer-sponsored pension plans. Over the last few decades, however, defined benefit plans have been steadily declining in importance relative to hybrid plans (e.g., cash balance plans) and defined contribution plans

\footnotetext{
11 National Association of Variable Annuities 2006.

${ }^{12}$ One must be careful to distinguish life annuities from other "annuity" products that do not provide lifetime payouts. According to that National Association of Variable Annuities (2006), over 94 percent of the \$212.3 billion of total annuity purchases was comprised of deferred annuities, which are sold primarily as tax-deferred saving vehicles (Brown and Poterba 2006) and which do not require conversion to lifetime payouts. Less than $0.8 \%$ of these contracts were converted into fixed life annuities in 2003 (Beatrice and Drinkwater, 2004).
} 
(e.g., 401(k) plans). ${ }^{13}$ As one study reports that as of 2002, "nearly all of the over 500” cash balance, or hybrid, plans offer lump-sum distributions as a payout option. ${ }^{14}$ It is also well known that in many defined contribution plans, such as the 401(k), participants often do not even have the option of annuitizing. For example, survey evidence of 401(k) plans sponsors conducted by Hewitt Associates found that the fraction of 401(k) plans offering annuities as a payout option feel from 31\% in 1999 to only $17 \%$ in $2003 .{ }^{15}$ Even in those DB plans that still exist, it is now very common for participants to have the option to take their benefits as a lump-sum. Over half of all defined benefit plans now offer a lump-sum distribution at retirement. ${ }^{16}$ As a result of these three factors, the Congressional Research reports that $85 \%$ of the 61.1 million workers age 21 or older who were included in a retirement plan at work participated in a plan that offered a lump-sum distribution as a payment option. ${ }^{17}$

With a tiny individual annuity market and a small and declining group annuity market, the only meaningful source of annuitization left in the U.S. today is the Social Security system. Evaluated solely as an annuity product, the Social Security benefit is quite good, in that it is inflation indexed (i.e., every January 1 benefits are increased by the amount of the Consumer Price Index) and provides spousal benefits. While individuals are permitted to claim Social Security benefits as early as age 62, they are not required to do so. Individuals who delay claiming are essentially purchasing (at better-than-market prices) a larger inflation-indexed annuity for the future. Research on benefit claiming behavior, however, suggests that very few

\footnotetext{
13 See Poterba, Venti and Wise (2007).

${ }^{14}$ Salisbury (2002).

${ }^{15}$ One reason for this - the legal environment - is discussed in section 6 .

${ }^{16}$ Salisbury (2002).

${ }^{17}$ Congressional Research Service (2005).
} 
individuals avail themselves of this opportunity, with only 1 out of 10 men retiring before their $62^{\text {nd }}$ birthday delay claiming benefits for at least a year. ${ }^{18}$

While public support for the Social Security program has historically been high, new survey evidence suggests that many individuals would prefer to receive their benefit as a lump sum. In an experimental module from the Health and Retirement Survey, approximately 1,000 participants were asked the following question: ${ }^{19}$

Imagine you are 65 years old, and you are receiving \$1000 per month in Social Security benefits. Suppose you were given the choice to lower that benefit by half, to $\$ 500$ per month. This one-half benefit reduction will continue as long as you live. In return, you would be given a one-time, lump sum payment of $\$ 87,000$. Would you take the $\$ 1000$ monthly benefit for life or the lower monthly benefit with the lump sum payment?

For married households, the dollar amount of the lump sum was $\$ 80,000$, reflecting the actuarial adjustment when switching from an individual to a joint-and-survivor annuity that Social Security provides to married couples. These amounts are approximately actuarially fair for an age-65 individual (the assumed age in the question), given average population mortality rates. Respondents were then asked a follow-up question that either increased or decreased the lumpsum amount by approximately 25 percent. Nearly 3 out of every 5 respondents stated a preference for the lump sum payment when it is priced at an actuarially fair level, and nearly 2 out of every 5 respondents preferred the lump-sum even when it was 25 percent below its actuarial value. Clearly, if the majority of respondents are willing to give up the best annuity they own for a lump sum that is worse than or equal to the actuarially fair level, most individuals are not behaving as if they place a high insurance value on the annuity.

\footnotetext{
${ }^{18}$ Coile, et al (2002)

${ }^{19}$ These results are analyzed in detail in Brown, Casey, and Mitchell (2007).
} 
Importantly, the limited degree of annuitization is not unique to the U.S. A series of World Bank studies in 1999 examined annuity markets in Canada, the UK, Switzerland, Australia, Israel, Chile and Singapore. The summary report states “annuities markets are still poorly developed in virtually all these countries.”20

In addition to the puzzle that individuals do not annuitize as often as theory would predict, a secondary puzzle pertains to those who do annuitize: the prevalence of "guarantees." The vast majority of private annuity products sold in the U.S. include guarantees, such as a "10 year period certain” feature that promises that the annuitant and/or the policy beneficiary will receive at least 10 years of payments, even if the annuitant dies during that period. This feature is somewhat puzzling in the standard life-cycle framework because it is easy to show that a life annuity with a 10-year period certain guarantee is simply a combination of a two distinct products: (i) a non-life contingent bond that pays back its principal plus interest over 10 years, and (ii) a life annuity with a deferred payout date of 10 years. ${ }^{21}$ Given that the loads charged for annuities with a 10-year guarantee are not substantially different from the loads charged for products that are entirely life contingent, it is not clear why individuals want to purchase the first of these products at existing loads, when plenty of alternative investments exist that would provide a better payout at comparable risk for the period of the guarantee. Another way to view this part of the annuity puzzle is that even when individuals are annuitizing, they are explicitly unraveling part of the annuity by including the guarantee.

\footnotetext{
20 James and Song (2001).

${ }^{21}$ This point has also been made by Scott, Watson and Hu (2006).
} 


\section{Can Rational Models Explain the Limited Demand for Annuities?}

An extensive literature has developed in recent years attempting to explain the lack of annuitization within the framework of a fully rational, optimizing agent. In this section, I argue that while it is possible to generate more limited annuitization by extending the rational model in several directions, such an approach does not seem to provide the complete answer to the puzzle. In some cases, the hypothesized explanations run counter to established empirical findings. In other cases, the explanations reduce the theoretical demand for annuities, but not by enough to explain such low observed levels. In still other cases, the explanations solve one puzzle at the expense of creating new ones.

\subsection{Adverse selection and high prices}

It has been well-documented that annuity prices (payouts) tend to be higher (lower) than actuarially fair levels. One commonly used metric for evaluating annuity prices is the “money's worth” concept, which is simply defined as:

$$
\text { Money's Worth }=\frac{\text { Expected Net Pr esent Value of Payouts }}{\text { Pr emium }}
$$

The numerator is the sum of all future annuity payments, weighted by the probability that an individual will be alive to receive them and discounted back to present at a risk free interest rate. The denominator is the premium paid for the annuity. Thus, when the MW ratio is less than 1.0, it indicates that individual annuitants will, on average, receive less in annuity payments than they paid in premiums. Analysis of market prices in 1999 found that the MW ratio for a single premium immediate annuity for a 65-year male in the U.S. was approximately 0.85 when evaluated using general population mortality and a Treasury yield curve. ${ }^{22}$ By computing the MW separately using general population and annuitant mortality tables, studies show that most

\footnotetext{
${ }^{22}$ Brown, Mitchell and Poterba (2002).
} 
of the load (where load = 1-MW) arises from the fact that the mortality rates of annuitants is substantially below that of the general population. These mortality differences reflect both adverse selection arising from private health information about expected longevity (i.e., "active" selection), as well as differences arising from the fact that annuitants tend to have higher income and wealth than non-annuitants, factors which are also correlated with mortality (i.e., "passive" selection"). ${ }^{23}$ Several papers reinforce the idea that active selection may matter by showing that individuals with poor self-reported health are less likely to express an interest in annuitizing. ${ }^{24}$ More recently, several papers have argued that part of the annuity load may also arise from the fact that insurance companies are unable to adequately hedge aggregate mortality risk in the population, and therefore must charge a higher price to compensate for bearing this risk. ${ }^{25}$

Regardless of the source of the price mark-up, however, the implicit assumption behind the belief that prices drive down annuity demand is that consumers are price sensitive, i.e., that they have a price elasticity of demand that is rather large (in absolute value). Perhaps surprisingly, we have relatively little in the way of empirical estimates about the price elasticity of demand for annuities. ${ }^{26}$ However, there are several pieces of data that suggest that existing loads are not the most important explanation of limited demand. First, simulation work suggests that the loads are not large enough to offset the utility gains from annuitization. ${ }^{27}$ Second, evidence suggests that few individuals are willing to postpone the claiming of Social Security benefits, despite the fact that the Social Security actuarial adjustments for early retirement are roughly actuarially fair on average. ${ }^{28}$ Finally, a recent study finds that nearly $3 / 5$ of the

${ }^{23}$ Finkelstein and Poterba (2002).

${ }^{24}$ See, for example, Brown (2001) or Brown, Casey and Mitchell (2007).

${ }^{25}$ See, for example, Blake and Burrows (2001), Blake, Cairns and Dowd (2006), Blake, Burrows and Orszag (2002), Friedberg and Webb (2006), Brown and Orszag (2006).

${ }^{26}$ See Gentry and Rothschild (2006) for further discussion of the issues involved.

${ }^{27}$ See, for example, Mitchell, et al (1999).

${ }^{28}$ See Coile et al (2002). 
population states a preference for a lump-sum to the Social Security annuity even when the trade-off is actuarially fair. ${ }^{29}$ Of course, this study did find some evidence of price sensitivity: when the lump-sum was reduced to 25 percent below the actuarially fair level, the proportion preferring the lump-sum dropped from 59 percent to 37 percent. In other words, a 33 percent (1/0.75) increase in the monthly annuity payout per dollar spent on the annuity is sufficient to induce only 1 out of 5 individuals to switch their stated preference from the lump-sum to the annuity. Given that most estimates of the money's worth of annuities in the private U.S. market suggest loads in the neighborhood of $10-15 \%$, a simplistic linear extrapolation suggests that less than $10 \%$ of the population would switch to an annuity if they suddenly became offered at actuarially fair prices.

Another way to view the pricing problem is that it may create an incentive to delay annuitization. Higher than actuarially fair prices, the irreversibility of the annuity contract and the potential arrival of asymmetric information may provide an advantage to delaying the purchase of annuities. ${ }^{30}$ For example, it may be optimal to delay annuitization if returns on investment in the future might exceed current returns, or if annuities purchased later in life are priced more favorably than those purchased earlier. Relatedly, an "all-or-nothing” annuitization decision at a single point in time is sub-optimal, and that consumers would be better off initially annuitizing a lump-sum (if they do not already have this minimum level from pre-existing DB pensions like Social Security) and then gradually purchasing additional life annuities over time. ${ }^{31}$ Of course, while these models provide excellent guidance about how people "ought to" behave when faced with realistic institutional restrictions on the timing and type of annuitization, they

\footnotetext{
${ }^{29}$ Brown, Casey and Mitchell (2007)

${ }^{30}$ Milevsky and Young (2002)

${ }^{31}$ Milevsky and Young (2002).
} 
share the shortcoming of being unable to explain how people actually behave: empirically, we do not observe many households following a strategy of gradual annuitization at older ages.

\subsection{Pre-existing annuitization}

Given standard models of lifetime expected utility, the marginal value of additional annuitization typically declines with the amount of wealth already annuitized. Numerous authors have made the point that high levels of pre-existing annuitization from Social Security or private defined benefit (DB) plans may lead to low demand for additional annuitization. ${ }^{32}$

For individuals at the low end of the wealth distribution, this explanation certainly rings true. For example, the Social Security Administration states that $21 \%$ of married couples and $43 \%$ of unmarried persons rely on Social Security for more than $90 \%$ of their income. ${ }^{33}$ It should not be surprising that these households would not wish to annuitize what little savings they have remaining. Higher up the wealth distribution, however, where Social Security represents a much smaller portion of wealth, it is more difficult to argue that all private annuity purchases are crowded out. As recently noted, "it would be a miraculous coincidence if the optimal partial annuitization strategy equaled the amounts provided by Social Security and defined benefit pensions for the vast majority of retirees.”34

\subsection{Risk sharing in couples}

It has long been noted that families who share a common budget constraint can effectively substitute for a formal annuity market. ${ }^{35}$ By pooling their resources, a married couple is able to capture a large share of the gains from a formal annuity market. As a result of this risk

\footnotetext{
32 This factor plays a particularly large role in Dushi and Webb’s (2004) model of limited annuity demand.

33 Social Security Administration (2007).

${ }^{34} \mathrm{Hu}$ and Scott (2007).

${ }^{35}$ Kotlikoff and Spivak (1981) were the first to rigorously evaluate this argument.
} 
sharing potential, a couple’s willingness to pay for joint and survivor annuities is substantially

lower than a single individual's willingness to pay for an annuity. ${ }^{36}$

One recent paper combines several of the preceding insights - high prices, high levels of pre-existing annuities, and risk sharing within couples - into a set of simulated annuity demands by individuals in the HRS, and finds that it is possible to explain observed low levels of annuitization. ${ }^{37}$ This suggests that while many of these explanations are inadequate, on their own, to explain limited annuity demand, the combination of multiple factors may have more success. However, this paper also confirms that annuity demand should be higher for single individuals than for couples. One implication of this is that we should observe individuals choosing to annuitized upon the death of a spouse, and yet we do not. Further, other research finds no significant difference between single and married individuals in terms of their likelihood of choosing the lump sum or the Social Security annuity. ${ }^{38}$

\subsection{Bequests}

Naturally, if a person wishes to leave an inheritance to their children, and if an annuity product has no value at death, then the individual will not find it optimal to annuitize all of their wealth. This is why the classic "full annuitization" result requires that there be no bequest motive. ${ }^{39}$ There are two problems, however, with viewing bequest motives as the answer to the annuity puzzle. First, while bequests clearly lead one away from the full annuitization result, it does not mean that individuals will not value partial annuitization. Indeed, under certain assumptions, an individual will simply wish to divide their wealth between "own consumption" and "heirs' consumption” and then fully annuitized the “own consumption” piece. The value of

\footnotetext{
${ }^{36}$ Brown and Poterba (2000).

${ }^{37}$ Dushi and Webb (2004).

${ }^{38}$ Brown, Casey and Mitchell (2007).

39 Yaari (1965).
} 
annuitizing the own consumption part of one's wealth would be particularly important if the individual (or, depending on the bequest function, the individual's children) are risk averse over the size of the bequest. The reason is that, in the absence of annuitization, the size of the bequest becomes a draw from a very disperse distribution - for example, the bequest might be quite large if the individual dies young, but quite small if the individual dies at age 95.

Second, the empirical evidence in favor of bequest motives mattering for marginal annuity decisions is essentially non-existent, at least in the widely used Health and Retirement Survey. For example, one study found that self-reported measures of the strength of the bequest motive could not explain intentions about the likelihood of annuitizing DC account balances at retirement. ${ }^{40}$ Another found that older adults with children are equally likely to annuitize as older adults with no children. ${ }^{41}$ Yet another study found that proxies for bequests, such as the number of children or whether the respondent has a will, are not correlated with one's stated preference for Social Security annuity versus a lump-sum. ${ }^{42}$

Bequest motives are sometimes also posited as an explanation for the frequency with which individuals purchase annuities with period certain guarantees. This explanation also seems unsatisfactory, however, due to the odd distribution of bequests that results from such a contract. Suppose, for example, that an individual purchased an annuity with a monthly payout of $\$ 1,000$, and a 10 -year period certain guarantee. If the person dies immediately after purchasing the annuity, the beneficiary receives 120 payments of $\$ 1,000$. If the annuitant dies after one year, the beneficiary receives only 108 payments of $\$ 1,000$. At the end of 10 years, the beneficiary receives nothing. Standard parameterizations of a bequest motive (whether a "warm glow" model or an altruistic model) have difficulty explaining why this particular distribution of

\footnotetext{
${ }^{40}$ Brown (2001).

${ }^{41}$ Johnson et al (2004).

${ }^{42}$ Brown, Casey and Mitchell (2007).
} 
bequests would be optimal. If there is any risk aversion over the size of the bequest, it is easy to show that a guarantee is dominated by purchasing a $\$ 1,000$ per month annuity with no guarantee and using the savings from the reduced annuity premium to make an immediate gift to the beneficiary. Indeed, if there is any load paid on the guarantee, even a risk neutral recipient would prefer the immediate gift.

\subsection{Incomplete annuity markets}

Recent theoretical work shows that as long as markets are complete, full annuitization is optimal. ${ }^{43}$ In reality, existing annuity markets in the U.S. and elsewhere are far from complete: most of the life annuity products that are sold today offer a fixed nominal payout, which leaves individuals exposed to other risks, such as from inflation or unexpected medical expenditures.

Inflation risk arises because most privately available annuity products are fixed in nominal terms. Simulation work shows that under a specific process for inflation, a moderately risk averse consumer would find nominal annuities less attractive than inflation-indexed annuities. ${ }^{44}$ However, it is difficult to conclude that the lack of inflation protection is the major culprit for the lack of annuity demand. Empirically, we know that when inflation-indexed annuities are provided - such as through TIAA-CREF's inflation-linked bond account, or through the CPI-indexed product offered by Vanguard / AIG - demand does not suddenly increase. Further, in the U.K. where inflation linked annuities have been widely available for many years, they represent a very small share of the market. ${ }^{45}$ Also, when individuals are given

\footnotetext{
${ }^{43}$ Davidoff, Brown and Diamond (2005).

${ }^{44}$ Brown, Mitchell and Poterba (2001) report these calculations for a moderately risk averse individual, assuming that inflation roughly captures the distribution of inflation outcomes over the period 1926 - 1997, and that inflation is correlated across periods.

${ }^{45}$ Finkelstein and Poterba (2002).
} 
the opportunity to choose between an inflation indexed Social Security annuity and a lump sum, 3 out of 5 individuals prefer the lump sum payment. ${ }^{46}$

A second problem with incomplete markets is that most annuity contracts are structured in a manner that imposes constraints on the degree of liquidity provided. It is generally not possible to borrow against the future value of an annuity, or to alter the timing of annuity payouts once a contract has commenced. Reversing an annuity, such as by selling it to a third-party buyer, is quite costly and often is not possible.

Concerns about liquidity often arise in the context of health care expenditures. Health expenditures are highly uncertain, not fully insured, and can be quite large especially at older ages. If expenditures are concentrated very late in life, then because annuities are able to provide a higher level of income in the years prior to the shock, annuities might be an effective way to save for such expenditures. ${ }^{47}$ Alternatively, if the expenditures come early in life, they may well reduce the value of annuities. Several papers analyze the role of medical expenditure shocks and find that they tend to reduce annuity demand. ${ }^{48}$ Of course, forgoing annuitization is an inferior strategy to buying both annuities and insurance against the shocks, such as long-term care insurance in the case of nursing homes. Similarly, one could offer a product that combines annuities and long-term care into a single product, which in addition to providing both types of insurance also has the potential benefit of improving pricing due to offsetting forms of adverse selection. ${ }^{49}$ Whether this approach would work depends in part on whether individuals will find the long-term care benefits valuable in their own right. For example, Medicaid imposes a large

\footnotetext{
${ }^{46}$ Brown, Casey and Mitchell (2007).

${ }^{47}$ See Davidoff, Brown and Diamond (2005).

${ }^{48}$ For example, see Sinclair and Smetters (2004) and Turra and Mitchell (2005).

49 This idea has been suggested by Murtaugh et al (2001).
} 
implicit tax on the purchase of private long-term care contracts, and to the extent this limits the market, this implicit tax would afflict combination products as well..$^{50}$

A more general problem with blaming the limited annuity market size on the incompleteness of the product space is that it begs the question of why insurance companies are not providing a richer mix of products in the first place. In some cases, it is easy to trace the blame to institutional barriers, such as the difficulty of obtaining level tax treatment of the combination annuity plus long-term care product. ${ }^{51}$ Similarly, it is understandable that many insurance companies have historically been reluctant to offer inflation-indexed annuities due to the lack of securities with which to hedge their inflation exposure. With the introduction of TIPS in the late 1990s, followed more recently by the "stripping" of the principal and interest from TIPS into separate securities, a few insurance companies have begun creating inflation indexed products. In many other cases, however, the market has been very slow to evolve despite the lack of any obvious external impediment to innovation. For example, aside from TIAA-CREF, insurers have been somewhat slow in providing lifetime annuity payouts linked to risky asset portfolios, such as stock indices. Another example is the limited availability of true deferred payout annuity contracts, in which an individual contributes gradually over time in exchange for a life contingent payout that starts at some future date in exchange for forfeiting the money if one dies prior to the payout date.

\footnotetext{
${ }^{50}$ See Brown and Finkelstein (forthcoming) for a rigorous treatment of Medicaid's implicit tax.

${ }^{51}$ Brazell et al (2007).
} 


\section{Possible Behavioral Hypotheses}

In recent years, the insights from psychology have increasingly been used to explain consumer behavior that deviates from what standard economic models would suggest in a very wide range of contexts. Just within the area of retirement planning, numerous papers have demonstrated the power of "behavioral economics" to explain savings rates, 401(k) plan participation rates and contribution levels, portfolio decisions and much more.

The literature on applying behavioral economics to the annuitization decision has yet to emerge. $^{52}$ Nonetheless, there are several reasons to believe that our understanding of annuity decisions will likely be informed by research in this area. First, the mixed success of explaining annuitization behavior in a fully rational context suggests that other factors are at play. Second, the insights from behavioral economics have been very influential in other aspects of the retirement and household finance literatures, and there is little reason to believe that if consumers are exhibiting psychological biases during their work lives that they will instantly switch to becoming fully rational optimizers at the point of retirement. Finally, anecdotal evidence (e.g., conversations with financial services providers, financial planners, and consumers), as well as some industry research, provides reason to believe that behavioral considerations loom large.

In this section, I outline an incomplete list of possible behavioral hypotheses that appear to be worth exploring in future research. While there are several research programs that are starting to apply behavioral economics to the annuity decision, few results are yet available, and thus it is too early to know which insights, if any, will prove most powerful and robust. As such, the discussion that follows is necessarily more speculative.

\subsection{Complexity and financial literacy}

\footnotetext{
${ }^{52}$ A notable exception is $\mathrm{Hu}$ and Scott (2007) whose discussion of these issues has been quite helpful in framing the analysis that follows.
} 
Determining how to provide for a sustainable retirement income stream in the face of uncertainty is a complex task, especially when the annuity product space is extremely confusing (such as the majority of products called “annuities” not providing any life-contingent payouts). In general, complexity and information problems may be a rational barrier to annuitization if the transactions costs associated with obtaining the necessary information are sufficiently high. In this context, however, where the potential welfare gains from optimizing one's retirement income plan are quite large, it is unlikely that consumers are making a fully rational decision to forgo educating themselves about annuities because of the perceived costs of doing so.

More likely, the average individual may simply lack the financial sophistication to make a fully informed decision about payouts. ${ }^{53}$ Evidence abounds about the lack of financial sophistication in the population. ${ }^{54}$ In the context of annuities, research suggests that, conditional on education, individuals who are able to answer a simple question about compound interest are significantly more likely to choose the Social Security annuity over the lump-sum option. ${ }^{55}$

Complexity is one of several hypotheses as to why default options have been found to have such power in influencing a wide range of behaviors associated with retirement planning. There is some evidence that defaults influence behavior in the wealth decumulation phase: in 1984, the federal government began requiring a spouse's notarized signature if a married retiree wished to opt-out of the joint-and-survivor annuity and take a single-life annuity instead, a change that increased joint-and-survivor annuitization of 5 to 10 percentage points. ${ }^{56}$ Of course,

\footnotetext{
53 Smith and Stewart (2007) documents that financial illiteracy is widespread.

${ }^{54}$ Lusardi and Mitchell (2006).

${ }^{55}$ Brown, Casey and Mitchell (2007).

56 Saku (2001).
} 
complexity is only one possible explanation for the importance of defaults, but all of them rely on behavioral, rather than fully rational, insights. ${ }^{57}$

\subsection{Mental Accounting and Loss Aversion: “Annuities are a Gamble”:}

In focus groups conducted by the American Council of Life Insurers, some participants viewed the purchase of an immediate annuity as "gambling on their lives." 58 This perspective is difficult to reconcile with the standard model of a life cycle consumer whose lifetime utility derives from their consumption each period and for whom the elimination of the financial aspect of mortality risk is a form of insurance.

Mental accounting and prospect theory’s loss aversion concept may help to explain this finding. Rather than evaluating the annuity as part of an overall optimization exercise, individuals may use a narrow framing along the lines of "will I live long enough to make back my initial investment?"59 If the question is framed in this manner, it is easy to then see why the product is viewed as a risky gamble. Without the annuity, the individual has $\$ 100,000$ for certain. With the annuity, in contrast, there is some positive probability that the individual will receive only a few thousand dollars in income (if he were to die within a few months), some probability that the individual will receive far more than $\$ 100,000$ (if he lives well past life expectancy), and a full distribution of possibilities in between. This line of reasoning suggests that if one applies the cumulative prospect theory approach to a narrow framing of the annuity, annuities do not look attractive because the "losses" from the annuity (if one dies young) loom larger in the individual's value function than do the potential "gains" from living a long time. ${ }^{60}$

\footnotetext{
57 These issues are more fully explored in Beshears et al (2006).

58 These findings are discussed in Brown and Warshawsky (2004).

${ }^{59} \mathrm{Hu}$ and Scott (2007) discuss this hypothesis in detail.

${ }^{60} \mathrm{Hu}$ and Scott (2007) discuss in detail how the application of Tversky and Kahneman's (1992) cumulative prospect theory to annuities might explain some of the observed behavior.
} 
In addition to providing a possible explanation of limited demand, proponents of this view argue that this can explain the prevalence of guarantees, which are essentially a way to hold less of the "risky" annuity. Of course, the use of prospect theory to explain why people purchase guarantees along with their annuity suffers from the difficulty that individuals who approach annuities from this perspective would prefer not to annuitize at all. There are a number of questions that need more research attention in this context, such as determining which reference point consumers use to evaluate gains and losses when evaluating an annuity. Nonetheless, this model provides a useful starting point for thinking about these issues.

\subsection{Misleading Heuristics: “Insurance is for Bad Events”,61}

An economist's view of insurance is that it is a mechanism for transferring resources from states of low marginal utility of income (i.e., times when additional money is less valuable) to states of high marginal utility of income (i.e., times when additional money is more valuable). An annuity does this by transferring resources from states of the world in which an individual has died young (and thus has a low marginal utility of income) to states in which they have lived past their expected lifespan and therefore presumably have a high marginal utility of income.

Casual empiricism suggests, however, that many non-economists use a different framing for buying insurance, such as, "I buy insurance against bad events.” In other words, many individuals appear to buy insurance to pay off when the level of utility is low, rather than when the marginal utility of income is high. In many cases, low utility and high marginal utility correspond, which is why this heuristic works well in cases such as life insurance, health insurance, casualty insurance, disability insurance, and so forth. However, there are also cases when this heuristic fails because marginal utility may be high even when utility is high, or vice versa. An example of a "high utility, high marginal utility" state might be the news that your

\footnotetext{
${ }^{61}$ I thank David Laibson for first suggesting this heuristic, and Richard Zeckhauser for additional insights on it.
} 
child has just been accepted into a very expensive private school: while you are happy with the outcome, you now place a high value on coming up with the marginal dollars to pay tuition. An example of a "low utility, low marginal utility" state might be the death of a child: the outcome itself is devastating, and you may value the marginal dollar less. Interestingly, we do not observe many insurance contracts written to insure against the good news of a child being accepted at Harvard, whereas it is quite easy to find examples of life insurance companies specifically targeting parents to purchase life insurance on their children.

To the extent that living a long time is viewed as a good or high utility outcome, this insurance heuristic may lead them to forego annuities. Of course, a good marketing strategy should be able to overcome this objection by re-framing the outcome as a negative event, along the lines of insuring against "being a widow living in extreme poverty because you outlived your money.” Whether such framing effects are really important remains to be seen, however, as there is virtually no empirical evidence to date that sheds any light on this hypothesis.

\subsection{Regret Aversion: "I Should Not Have Bought that Annuity”}

A common explanation proffered by financial planners as to why their clients do not like annuities, and for the popularity of period certain guarantees for those that do buy them, is the desire to avoid regret. One possible response to this notion is that the time in which the individual should most regret the annuity purchase is after they are dead, at which time the capacity for regret seems speculative at best. This response, however, ignores the possibility that if an individual converts the majority of their retirement savings into an annuity and then subsequently learns they have only one year to live, the potential for regret during that final year of life may be significant. Even if the probability of this outcome is very small, individuals may inflate the probability in making the annuity decision. For example, research in psychology has 
shown that events that are more easily imagined (e.g., such as dying right after an annuity purchase) are over weighted in the decision process. ${ }^{62}$

However, a formal application of the regret aversion model to annuities does not necessarily imply that individuals will not value annuities. In a study that examines insurance decisions within a formal model of regret aversion, researchers find that regret aversion leads individuals away from extreme outcomes, meaning that regret averse individuals are less likely to fully insure but also less likely to forego insurance completely. ${ }^{63}$ In this context, just as individuals might regret the decision to purchase an annuity, a regret averse individual might also fear the possibility of living to age 110 after having failed to purchase one. More research needs to be done to determine whether or not regret aversion matters for the annuity purchase decision.

\section{5 "The Illusion of Control"}

One recent industry study finds that "loss of control" of one's assets is the most commonly cited disadvantage of annuitization. ${ }^{64}$ To the extent that individuals are really expressing a concern about liquidity, there is a rational element to this objection. As noted earlier, the "costly reversibility” feature of life annuities and the difficulty borrowing against future annuity streams means that individuals who may face uninsured expenditure shocks may not want to fully annuitized. It may also be rational to be concerned about control if one is concerned about entering into a long-term contract with an insurance company that may go bankrupt sometime during the life of the annuity contract. ${ }^{65}$ However, the strength of the objections often registered about control suggests that there is something deeper than a rational concern about liquidity.

\footnotetext{
62 Tversky and Kahneman (1974).

${ }^{63}$ Braun and Muermann (2003).

${ }^{64}$ LIMRA International (2006).

${ }^{65}$ Babbel and Merrill (2006).
} 
It is possible that these objections may be related to the large psychology literature on the "illusion of control," or the tendency of individuals to believe they can control outcomes even when they have no such control. ${ }^{66}$ Individuals may well believe that they have more control over their financial future by holding wealth rather than by receiving income. It is worth noting that during one's working life, much of the financial advice that one receives emphasizes individual choice and control. Thus, it would not be surprising to think that individuals would have a difficult time handing over their wealth to an insurance company in exchange for a monthly income stream over which they have little control.

\subsection{Other Behavioral Factors}

There are numerous other potential behavioral explanations as well, including models of ambiguity aversion (e.g., people do not even know the relevant probabilities of survival), models that suggest that individuals do not like to think about unpleasant events (e.g., dying young, or being old but poor), and models focusing on how individuals discount the future (e.g., a hyperbolic discounting model). ${ }^{67}$ It is also possible that "framing” effects are quite important in this context. As with the other hypotheses outlined above, however, much more research is needed to determine which of these factors, if any, are empirically relevant.

\section{The Future of Annuitization}

\subsection{New products ${ }^{68}$}

With nearly 80 million baby boomers approaching retirement, the issue of how to convert wealth into a secure stream of retirement income is increasingly on the minds of individuals, insurance companies, and policy makers. In the last few years, insurance companies have started

\footnotetext{
${ }^{66}$ Langer (1975).

${ }^{67}$ Laibson (1997) provides a formal modeling of hyperbolic discounting.

${ }^{68}$ Warshawsky (2007) provides a more detailed discussion of many of these new products.
} 
introducing several new products that focus on the payout phase, a small subset of which will be described below. The diversity of approaches being followed in the industry suggests that there is not unanimity about the underlying cause of limited annuitization. As the market evolves in the coming years, it will provide us with additional information to assess the underlying determinants of, and barriers to, annuitization.

\subsubsection{Deferred payouts}

Several companies have begun to offer products that are designed to provide life annuity payments that start at some future date. ${ }^{69}$ At least one company (Hartford) has structured a product to be similar to having a DB option within a 401(k) plan: as a person contributes, they are buying a guaranteed amount of future annuity income. One possible advantage of this approach is that because the individual is gradually buying units of income, rather than accumulating wealth per se, participants may not face the same psychological barrier of converting a large accumulated stock of wealth into income at the time of retirement.

A related product was introduced by MetLife in 2004. The idea behind this product is that a consumer at age 65 can use a small portion of their wealth to buy an annuity that does not begin paying out until age 85 . In this sense, the product feels more like insurance in that it pays off only in the event that the person lives a long time. Because payouts commencing 20 years in the future are being discounted by both interest rates and non-trivial mortality rates, it appears relatively "cheap” to buy income at older ages. By providing insurance against outliving one’s resources, this product captures a disproportionate share of the welfare gains from annuitization. ${ }^{70}$ One way to view it is that it is a form of partial annuitization where the annuitization is concentrated in those periods where the mortality credits are the largest. While

\footnotetext{
${ }^{69}$ Milevksy (2004) refers to these products as “Advanced-Life Delayed Annuities.”

${ }^{70}$ This has been shown by Scott et al (2006).
} 
these products seem to be generating a fair amount of interest in the financial planning community, only time will tell if they have a major impact on the market.

\subsubsection{Guaranteed minimum withdrawals for life}

As noted earlier, variable annuity products have traditionally been used as asset accumulation devices, with little attention paid to the payout features. Recently, however, a "new generation of variable annuity products (is) proliferating in the market."71 An increasingly popular feature of these contracts is a guaranteed minimum withdrawal benefit (GMWB) that guarantees a minimum level of withdrawals over one's lifetime. Because these contracts typically guarantee that the individual will receive a fixed percentage (e.g., 5\%) of the account balance at a point in time (e.g., a particular birthday, a high-water mark, etc), they are essentially providing the owner with an annuity floor below which the income cannot fall. These contracts typically provide individuals with a reasonably high level of liquidity (e.g., they may modify their withdrawal amount, or even cash in the product) as well as some control over the portfolio allocation. GMWB were available on nearly 80 percent of the variable annuities sold in the first

quarter of 2006, up from 44 percent in $2003 .^{72}$ To what extent individuals take advantage of this annuity feature after retirement remains to be seen.

\subsubsection{Annuities with liquidity}

At least one insurance company that offers a fixed life annuity with an option to withdraw, on a one-time only basis, up to 30 percent of the expected value of the remaining annuity payments based on mortality rates at the time of purchase. This option is limited to being exercised only on the $5^{\text {th }}, 10^{\text {th }}$, or $15^{\text {th }}$ anniversary of the first payment or upon a

\footnotetext{
${ }^{71}$ Prudential Financial (2006).

${ }^{72}$ Prudential Financial (2006).
} 
"significant, non-medical loss."73 It is not yet clear whether the potential for adverse selection in this context has affected the pricing in a significant way.

Another idea that has been floated is that of combining an annuity with long-term care insurance as a way of addressing concerns about liquidity in the context of long-term care expenditure risk. $^{74}$ The idea of the product is that it would provide life annuity benefits with a significant “pop-up” benefit (e.g., additional cash payments) when the annuitant meets the benefit triggers typically associated with long-term care insurance policies. While the Pension Protection Act of 2006 provided this combination product with some tax benefits beginning in 2010, it is too early to know whether this market will evolve in a substantial way.

\subsection{Public policy towards annuitization}

Whether policymakers should be actively encouraging annuitization is unclear, as it depends on why individuals are choosing not to annuitize on their own. If the observed lack of annuitization represents optimal behavior by fully rational individuals, then the scope for welfare-increasing government intervention is more limited. Even if individuals are failing to fully optimize as a result of behavioral biases, it is not clear that government intervention is necessary or desirable in overcoming it, as private sector annuity providers may have sufficient incentive to determine how to promote annuitization on their own.

On the other hand, given that pensions and insurance are heavily regulated at the federal and state level respectively, there is no question that the government is already influencing the annuity landscape, and not always for the better. For example, an important reason for the lack of annuities in 401(k) plans is that legal advisors "strongly advise their clients against them. In their view, annuities expose plan sponsors to significant and long-term risk of liability. And plan

\footnotetext{
${ }^{73}$ Warshawsky (2007) discusses this product in more detail.

${ }^{74}$ Murtaugh, et al (2001) have promoted this idea.
} 
sponsors, more often than not, heed their advice. ${ }^{, 75}$ While plan sponsors are under no fiduciary risk for choosing not to provide an annuity option, the decision to offer an annuity creates such risk due to a provision requiring plan sponsors to choose the "safest annuity available." At a minimum, it would seem desirable that the government not discourage annuitization. Fortunately, this risk may be mitigated in the future, as Section 625 of the Pension Protection Act of 2006 directs the Department of Labor to issue regulations within one year that would clarify that when a fiduciary selects an annuity as an optional form of distribution from a defined contribution plan, the decision will no longer be subject to the "safest available" provision. ${ }^{76}$

The Pension Protection Act also took significant steps to encourage the use of default options in the accumulation phase of 401(k) plans. Given the demonstrated power of default options, it is perhaps worth considering whether firms ought to be required to offer an annuity as a default payout option. Structuring an optimal annuity default would arguably be more challenging than designing a default for contributions due to the issues of irreversibility, but such issues could likely be addressed by allowing for a richer set of annuity options (e.g., gradual annuitization, liquidity options, etc).

\section{Conclusions and Implications for Financial Education}

It has been more than two decades since Nobel Laureate Franco Modigliani stated that the reasons individuals do not annuitize more are still "ill-understood.” Since that time, numerous scholars have contributed to a significant increase in our understanding of how annuity markets operate, the decisions that individuals make, and the implications of these decisions for individual welfare. Nonetheless, while we have a much greater understanding of how we think

\footnotetext{
${ }^{75}$ Perun (2004).

${ }^{76}$ Borzi and Patterson (2007).
} 
consumers ought to optimally behave and of how they actually do behave with respect to annuity decisions, we still do not have a fully developed sense of why they behave the way that they do. The answers to these questions are critical for understanding the appropriateness and/or potential efficacy of financial education in this area. If future research were to show that consumer aversion to annuities is well-informed and rational, then there is minimal scope for financial education or other forms of government intervention to alter outcomes (nor in this case would altering outcomes be desirable). If research confirms that consumer aversion is driven primarily by complexity, confusion, or various psychological biases, then the next question is whether scarce societal resources are better spent on financial education or on creating products and policies that mandate or encourage annuitization by appealing to or overcoming such biases. Until we have a better understanding of why consumers act as if they place so little value on annuitization, it will remain unclear whether individual and social welfare will be enhanced by policies that promote annuitization, or even which policies would be successful at doing so. As such, the economics and psychology of the annuitization decision remains a very fruitful area for additional research. 


\section{References}

Babbel, David F. and Craig B. Merrill. 2006. "Rational Decumulation.” Unpublished.

Beatrice, Dan Q. and Matthew Drinkwater. 2004. “The 2003 Individual Annuity Market: Sales and Assets.” Windsor, CT: LIMRA International.

Bernheim, B. Douglas. 1987. “The Economic Effects of Social Security: Toward a Reconciliation of Theory and Measurement.” Journal of Public Economics, 33(3): 273 - 304.

Beshears, John, James J. Choi, David Laibson, and Brigitte C. Madrian. 2006. "The Importance of Default Options for Retirement Saving Outcomes: Evidence from the United States.” Working paper.

Blake, D and W. Burrows. 2001. “Survivor Bonds: Helping to Hedge Mortality Risk.” Journal of Risk and Insurance. 68(2): 339-348.

Blake, D., A.J.G. Cairns, and K. Dowd. 2006. "Living with Mortality: Mortality Bonds and Other Mortality-Linked Securities.” British Actuarial Journal.

Blake, D., W. Burrows and J. Michael Orszag. 2002. "Survivor Bonds and Compulsory Annuitization: Reducing the Costs of Pension Provision.” In Olivia Mitchell, ed., Innovations in Retirement Financing. Philadelphia, PA: Pension Research Council: 222-233.

Borzi, Phyllis C. and Martha Priddy Patterson. 2007. "Regulating Markets for Retirement payouts: Solvency, Supervision and Credibility.” Unpublished.

Braun, Michael and Alexander Muermann. 2003. "The Impact of Regret on the Demand for Insurance.” Unpublished.

Brazell, David, Jason Brown and Mark J. Warshawsky. 2007. "Combination of Life Annuities and Long-term Care Insurance: Tax Issues.” Unpublished.

Brown, Jeffrey R. 2001. "Private Pensions, Mortality Risk, and the Decision to Annuitize." Journal of Public Economics,82(1): 29-62.

Brown, Jeffrey. 2004. “The New Retirement Challenge.” White for Americans for Secure Retirement. Available at www.paycheckforlife.org.

Brown, Jeffrey R. and Amy Finkelstein. Forthcoming. "The Interaction of Public and Private Insurance: Medicaid and the Long-Term Care Insurance Market.” American Economic Review.

Brown, Jeffrey R., Marcus Casey and Olivia S. Mitchell. 2007. "Who Values the Social Security Annuity? Evidence from the Health and Retirement Study." Unpublished.

Brown, Jeffrey R. and Peter Orszag. 2006. "The Political Economy of Government-Issued Survivor Bonds.” Journal of Risk and Insurance. Vol 73(4) December pp. 611-631.

Brown, Jeffrey R., Olivia S. Mitchell and James M. Poterba. 2001. "The Role of Real Annuities and Indexed Bonds in an Individual Accounts Retirement Program,” in J. Campbell and M. Feldstein, Risk Aspects of Investment-Based Social Security Reform, University of Chicago Press: Chicago, IL, pp. 321-360.

Brown, Jeffrey R., Olivia S. Mitchell and James M. Poterba. 2002. "Mortality Risk, Inflation Risk, and Annuity Products,” in O. Mitchell, Z. Bodie, B. Hammond, and S. Zeldes, Innovations in Retirement Financing, University of Pennsylvania Press: Philadelphia, PA, pp. 175 - 197.

Brown, Jeffrey R. and James M. Poterba. 2000. “Joint Life Annuities and the Demand for Annuities by Married Couples,” The Journal of Risk and Insurance, 67(4): pp. 527 - 553.

Brown, Jeffrey R. and James M. Poterba. 2006. "Household Demand for Variable Annuities,” Tax Policy and the Economy. 
Brown, Jeffrey R. and Mark J. Warshawsky. 2004. "Longevity-Insured Retirement

Distributions from Pension Plans: Regulatory and Market Issues,” in W. Gale, J. Shoven and M. Warshawsky, Ed., Public Policies and Private Pensions, Brookings Institution.

Coile, Courtney, Peter Diamond, Jonathan Gruber and Alain Jousten. "Delays in Claiming Social Security Benefits.” Journal of Public Economics. Vol. 84(3), 357-385.

Congressional Research Service. 2005. "Pension issues: Lump-Sum Distributions and Retirement Income Security.” CRS Report for Congress. August 3, 2005.

Davidoff, Thomas, Jeffrey R. Brown and Peter A. Diamond. 2005. "Annuities and Individual Welfare.” American Economic Review. 95(5), 1573 - 1590.

Dushi, Irena, and Anthony Webb. 2004. "Household Annuitization Decisions: Simulations and Empirical Analysis.” Journal of Pension Economics and Finance. 3(2): 109 - 43.

Finkelstein, Amy and James Poterba. 2002. "Selection Effects in the United Kingdom Individual Annuities Market.” The Economic Journal. 112(476): 28-50.

Friedberg, Leora and Anthony Webb. 2006. "Life is Cheap: Using Mortality Bonds to Hedge Aggregate Mortality Risk.” Working paper CRR WP 2005-12, Boston College Center for Retirement Research.

Gentry, William and Casey Rothschild. 2006. "Lifetime Annuities for US: Evaluating the Efficacy of Policy Interventions in Life Annuity Markets.” Paper prepared for the American Council for Capital Formation (available at www.accf.org).

Hu, Wei-Yin and Jason S. Scott. 2007. "Behavioral Obstacles to the Annuity Market.” SSRN Working Paper. March.

James, Estelle and Xue Song. 2001. “Annuities Markets Around the World: Money’s Worth and Risk Intermediation.” Working paper.

Johnson, Richard W., Leonard E. Burman, and Deborah Kobes. 2004. "Anuitized Wealth at Older Ages: Evidence from the Health and Retirement Study.” Washington DC: The Urban Institute.

Kotlikoff, Laurence J. and Avia Spivak. 1981. “The Family as an Incomplete Annuities Market.” Journal of Political Economy. 89(2): 372-391.

Laibson, David. 1997. “Golden Eggs and Hyperbolic Discounting.” Quarterly Journal of Economics. 62(May): 443-77.

Langer, Ellen J. “The Illusion of Control.” Journal of Personality and Social Psychology. 32(2): $311-328$.

LIMRA International 2006. "Retirement Income Preferences.”

Lusardi, Annamaria, and Olivia S. Mitchell. "Baby Boomer Retirement Security: The Roles of Planning, Financial Literacy, and Housing Wealth.” Journal of Monetary Economics. 54(1).

Milevsky, Moshe Arye. 1998. "Optimal Asset Allocation Towards the End of the Life Cycle: To Annuitize or Not to Annuitize?” Journal of Risk and Insurance Vol. 65, No. 3, 401-426. Milevksy, Moshe Arye. 2004. "Real Longevity Insurance with a Deductible: Introduction to Advanced-Life Delayed Annuities.” Society of Actuaries.

Milevsky, Moshe Arye and Virginia R. Young. Forthcoming. "Annuitization and Asset Allocation.” Journal of Economic Dynamics and Control.

Mitchell, Olivia S., James M. Poterba, Mark J. Warshawsky and Jeffrey R. Brown. 1999. “New Evidence on the Money's Worth of Individual Annuities.” American Economic Review. 89(5): 1299-1318.

Modigliani, Franco. 1986. "Life Cycle, Individual Thrift and the Wealth of Nations." Nobel Prize acceptance speech, reprinted in The American Economic Review, 76(3): 297 - 313. 
Murtaugh, Christopher, Brenda Spillman and Mark J. Warshawsky. 2001. "In Sickness and in Health: An Annuity Approach to Financing Long-Term Care and Retirement Income.” Journal of Risk and Insurance, Vol. 68, No. 2. June. Pp. 225 - 254.

National Association of Variable Annuities. 2006. Annuity Fact Book. $5^{\text {th }}$ edition.

Perun, Pamela. 2004. "Putting Annuities Back into Savings Plans.” Working paper presented at the Society of Actuaries Symposium on Managing Retirement Assets, April 1, 2004.

Poterba, James M., Steven Venti, and David A. Wise. 2007. “The Changing Landscape of Pensions in the United States." Working paper presented at Improving the Effectiveness of Financial Education and Savings Programs” conference.

Prudential Financial. 2006. "Learning the Two-Step: A New Approach to Asset Allocation for the Retiree.” Prudential Financial white paper.

Saku, Aura. 2001. 'Does the Balance of Power Within a Family Matter? The Case of the Retirement Equity Act.’ IGIER Working Paper 202. Milan, Italy: Innocenzo Gasparini Institute for Economic Research.

Salisbury, Dallas. 2002. "Statement before the committee on Ways and Means, Subcommittee on Oversight, United States House of Representatives. Hearing on Retirement Security and Defined Benefit Pension Plans.” June 20, 2002.

Scott, Jason S., John G. Watson, and Wei-Yin Hu. 2006. “Efficient Annuitization with Delayed Payout Annuities.” Financial Engines working paper.

Sinclair, Sven H. and Kent A. Smetters. 2004. "Health Shocks and the Demand for Annuities." Congressional Budget Office Technical Paper Series: No. 2004-09.

Smith, Barbara and Fiona Stewart. "Learning from the Experience of OECD Countries: Lessons for Policy, Programs and Evaluations.” Working paper presented at Improving the Effectiveness of Financial Education and Savings Programs” conference.

Social Security Administration. 2007. "Fact Sheet." Available at www.ssa.gov/pressoffice/factsheets/basic-fact-alt.pdf accessed on May 7, 2007.

Turra, Cassio M. and Olivia S. Mitchell. 2005. “The Impact of Health Status and Out-of-Pocket Medical Expenditures on Annuity Valuation.” University of Michigan, Retirement Research Center Research Brief: No. RB 2005-079.

Tversky, Amos and Daniel Kahneman. 1974. “Judgment under Uncertainty: Heuristics and Biases.” Science. 185(4157): $1124-1131$.

Tversky, Amos and Daniel Kahneman. 1992. "Advances in Prospect Theory: Cumulative Representation of Uncertainty." Journal of Risk and Uncertainty. 5: 297 - 323.

Warshawsky, Mark J. 2007. "Recent Developments in Life Annuity Markets and Products.” Watson Wyatt working paper.

Yaari, Menahem E. 1965. "Uncertain Lifetime, Life Insurance, and the Theory of the Consumer.” Review of Economic Studies. 32(2): 137 - 50. 
Figure 1

Income from Alternative Payout Strategies

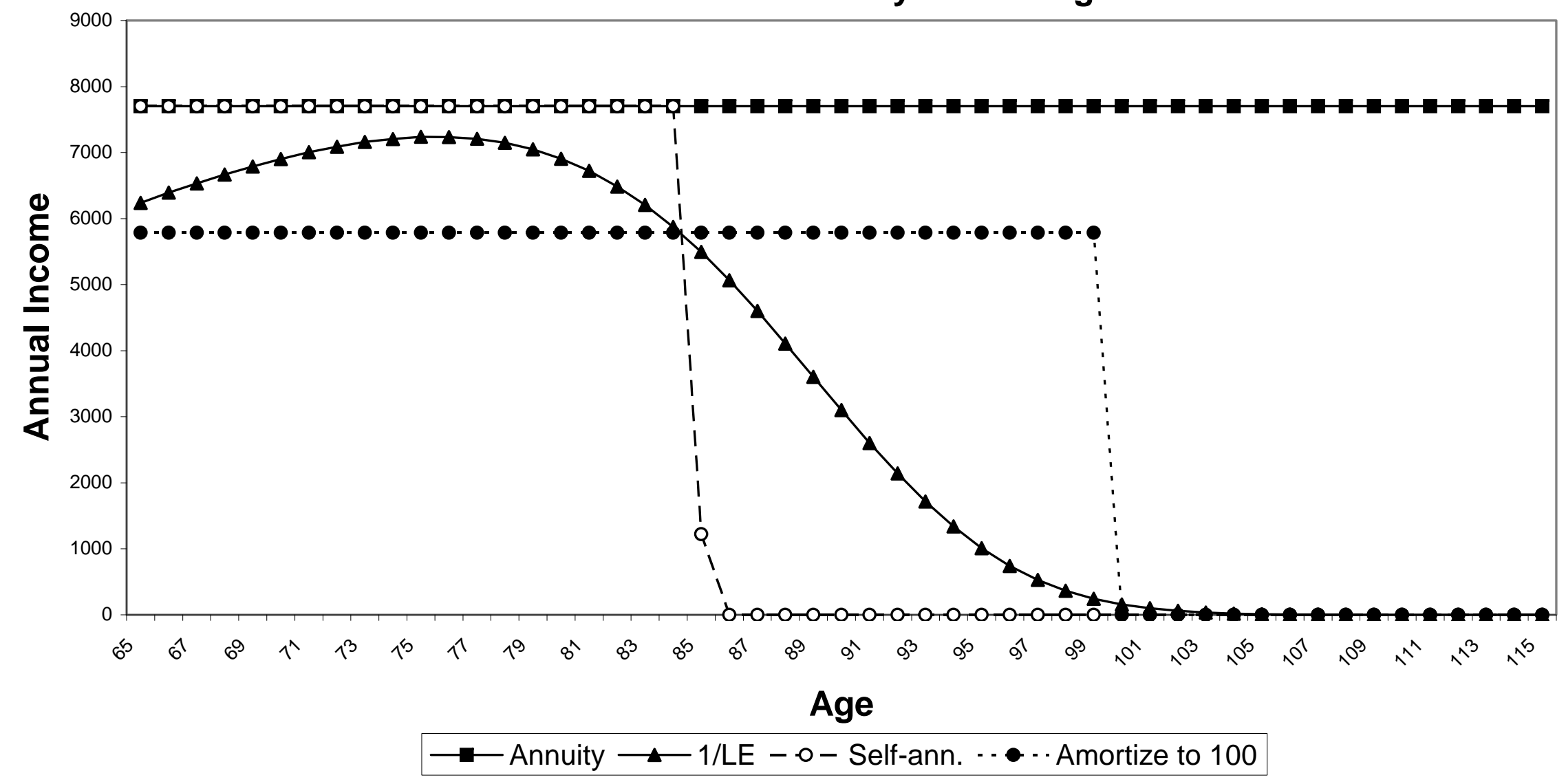

